\section{Further thoughts about the ILLUMINATE studies of tabalumab in SLE}

Chiche and colleagues make some very pertinent comments about the apparent failure of Tabalimumab (in the ILLUMINATE trials) set against the 'deemed' success of Benlysta (in the BLISS trials) when in fact an analysis of the results indicates that there is little to choose between them.

I would point out that the least successful of these four trials, ILLUMINATE 1 , was not helped by the decision made by the company to consider patients who changed their concomitant dose of steroids to have failed the trial even if that change was a reduction in the steroids. The authors also suggest that the failure to 'label', that is, approve, Benlysta in the UK was because its effects were too modest. This was indeed part of the issue but the other aspect was the very high price (around $\$ 30000$ per patient per annum).

They further propose that B-lymphocyte stimulator (Blys)/ B-cell activating factor (BAFF) levels at baseline are insufficient to define likely responders to B cell targeted therapy. My colleagues and I have pointed out elsewhere ${ }^{1}$ that a group of patients with SLE responds to rituximab with a rapidly rising BLyS level which has led us to prose a trial in which rituximab followed by Benlysta will be evacuated (BEAT-lupus). In my opinion it is often clinical trial design which mitigates against success in SLE clinical trials. I think, in particular, that unreasonable targets-setting the bar too high, coupled with an excess of steroids and immunosuppressives used have made it very hard indeed for primary end points to be achieved.

\section{David Isenberg}

Correspondence to Professor David Isenberg, Division of Medicine, UCL, Centre for Rheumatology Research, London WC1E 6JF, UK; d.isenberg@ucl.ac.uk

Competing interests None declared.

Provenance and peer review Commissioned; internally peer reviewed.

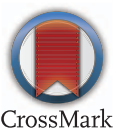

To cite Isenberg D. Ann Rheum Dis 2016;75:e11.

Received 5 October 2015

Accepted 10 October 2015

Published Online First 3 November 2015

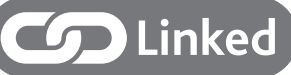

http://dx.doi.org/10.1136/annrheumdis-2015-208702

Ann Rheum Dis 2016;75:e11. doi:10.1136/annrheumdis-2015-208709

\section{REFERENCE}

1 Carter L, Isenberg DA, Ehrenstein MR. Elevated serum BAFF levels are associated with rising anti-doubled-stranded DNA antibody levels and disease flare following $B$ cell depletion therapy in systemic lupus erythematosus. Arhritis Rheum 2013;65:2672-9. 